\title{
Dithienopyrrole-based monomers as an acceptor unit building for synthesis of donor - acceptor conjugated polymers
}

- Tam Huu Nguyen ${ }^{2}$

- Thu Anh Nguyen ${ }^{1}$

- Viet Quoc Nguyen ${ }^{1}$

- Trung Thanh Nguyen ${ }^{2}$

- Ha Tran Nguyen ${ }^{2}$

${ }^{1}$ National Key Lab of Polymer and Composite Materials, VNU-HCM.

${ }^{2}$ Faculty of Materials Technology, HCM city University of Technology,VNU-HCM.

(Manuscript Received on October 27th, 2015, Manuscript Revised July 04th, 2016)

ABSTRACT

A new monomer of N-benzoyl structures of monomers were confirmed via the dithieno[2,3-b:2',3'-d]pyrrole (BDP), has been successfully prepared via copper-catalyzed amidation. Then, this monomer was brominated nuclear magnetic resonance (1HNMR) and Fourier transform infrared (FT-IR). BDP and DiBDP monomers will be used as monomers for to form 2,6-dibromo-n-benzoyl dithieno[2,3Suzuki polycondensation reaction to synthesize $b: 2$ ',3'-d]pyrrole (DiBDP) monomer. The the donor-acceptor (D-A) conjugated polymers.

Keywords: Donor-acceptor (D-A) conjugated polymers, Polymeric solar cells, Suzuki polycondensation.

\section{INTRODUCTION}

Polymer solar cells (PSCs) have attracted great interests in both academic and industry because of their various distinctive advantages including flexibility, simple manufacturing techniques, ability to incorporate other technologies, low material cost [1]. At the meantime, despite of their advantages, PSCs have some drawback and other technical limitations that they have low stability, low power conversion efficiency and short lifetime [2]. Consequently, enormous efforts have been devoted to overcome these weaknesses as well as to improve the operated efficiency of PSCs. An effective way to broaden absorption of PSCs is to narrow their band gaps. Recently, one of the most concerned research direction to do so is to alternatively bind an electron-rich units (D) and an electron-deficient units (A) into the same 
polymer backbone [3]. For this kind of polymers, the interactions between the donor segments and the acceptor segments will form a new higher HOMO level and a new lower LUMO level. Through the interaction between push - pull driving forces, the electrons will redistribute from the initial orbitals (before interacting) to the new hybridized orbitals of the polymer. As a result, the magnitude of the band gap will be reduced. The degree of band gap reducing depends much on the strength of the donor, acceptor units imposed in the polymer backbone. Therefore, judicious selection of donor, acceptor segments can allow to adjust the band gap magnitude to the expected value.

Experimentally, it is recognized that the narrower the optical band gap, the stronger the electron-withdrawing ability of acceptor unit in the copolymer [4]. Besides that, the combinations of medium/strong donor units and medium/strong acceptor units usually result in good photovoltaic performances (PCE > $5 \%$ ) [511]. From that, medium and strong acceptor units are believed to be a good choice for effective DA conjugated polymer [12,13]. Therefore, in recent years, the $N$-acyl dithieno[2,3-b:2',3'd]pyrrole (DTP) moieties have been received considerable interest due to their good planar crystal structure, strong electron-withdrawing ability and symmetrical chemical structure with the side chain at the bridging unit [14-16]. The foregoing leads to materials with low band gaps and high mobility. These structures can be incorporated into various polymeric, oligomeric and molecular materials with a great desire to construct different low band gap donor - acceptor conjugated polymers which are useful in a large variety of applications such as OLED, FET, and photovoltaic cells.
Thus aim of this study is to synthesize the monomer $N$-benzoyl dithieno[2,3-b:2',3'd]pyrrole (BDP) which is DTP derivative and brominated $\mathrm{BDP}$ in order to prepare 2,6dibromo- $n$-benzoyl dithieno[2,3-b:2',3'd]pyrrole (DiBDP) monomer. These building monomers can be used to copolymerized with other electron-donating building blocks for synthesis of the D-A conjugated copolymers.

\section{EXPERIMENT}

\subsection{Materials}

3,3'-dibromo-2,2'-bithiophene (98\%); n',ndimethylethylene diamine (DMEDA, 95\%), copper (I) iodide (CuI, 98\%) were purchased from AK Scientific and used as received. Benzamide (99\%) was purchased from Sigma Aldrich. N-bromosuccinimide (NBS, 99\%) was purchased from Merck. Chloroform $\left(\mathrm{CHCl}_{3}\right.$, Fisher Scientific, 99\%), toluene (Merck, 99\%), $n$ heptane (Labscan, 99\%) and diethyl ether (Merck, 99\%) were used as received. All reactions were carried out in oven-dried flask under purified nitrogen.

\subsection{Characterization}

Attenuated total reflection Fourier transform infrared (ATR FT-IR) spectra were recorded using BIO-RAD Excalibur spectrometer equipped with an ATR Harrick Split PeaTM.

${ }^{1}$ HNMR spectra of the compounds were recorded in deuterated chloroform $\left(\mathrm{CDCl}_{3}\right)$ with a $500 \mathrm{MHz}$ spectrometer - Bruker AMX500 apparatus, and the chemical shift are given relative to tetra methyl silane (TMS).

2.3. Synthesis of $N$-benzoyl dithieno[2,3b:2',3'-d]pyrrole monomer

To a $50 \mathrm{~mL}$ rounded-bottomed flask equipped with a magnetic stirrer was added copper iodide 
(0.19 g, $1 \mathrm{mmol})$, DMEDA (1.728 mL, $8 \mathrm{mmol})$, potassium carbonate $(4.15 \mathrm{~g}, 30 \mathrm{mmol})$, followed by evacuation and backfilling with nitrogen. Then, toluene was added to the reaction mixture and the solution was stirred for 30 minutes. Benzamide (12 mmol) was added, followed by 3,3'-dibromo-2,2'-bithiophene (3.24 g, 10 mmol). The reaction mixture was stirred for 24 hours at $110{ }^{\circ} \mathrm{C}$. The reaction was cooled to the room temperature in the next step, washed with distilled water $(3 \times 20 \mathrm{~mL})$ and extracted with chloroform (3 x $20 \mathrm{~mL})$. The organic phase was dried by anhydrous $\mathrm{K}_{2} \mathrm{CO}_{3}$. The solvent was removed by rotary evaporation. The crude product was purified by silica gel column chromatography (with the eluent as following -4 $n$-heptane: 1 ethyl acetate) to give the isolated product as a white crystalline solid $\left(3.82 \mathrm{~g}, \mathrm{R}_{\mathrm{f}}=\right.$ 0.75 , yield $=45.29 \%$ ).

${ }^{1} \mathrm{HNMR}\left(500 \mathrm{MHz}, \mathrm{CDCl}_{3}\right), \delta(\mathrm{ppm}) 7.73$ (d, 2H), $7.65(\mathrm{t}, 1 \mathrm{H}), 7.55(\mathrm{t}, 2 \mathrm{H}), 7.1(\mathrm{~d}, 2 \mathrm{H}), 6.85$ (br s, 2H)

\subsection{Synthesis of 2,6-dibromo-n-benzoyl} dithieno[2,3-b:2',3'-d]pyrrole monomer

To a solution of compound $N$-benzoyl dithieno[2,3-b:2',3'-d]pyrrole (1.014 g, 3.56 mmol) in $30 \mathrm{~mL}$ chloroform was added $N$ bromosuccinimide (NBS) (1.25 g, $7 \mathrm{mmol})$ at 0 ${ }^{\circ} \mathrm{C}$, followed by evacuation and backfilling with nitrogen. The mixture was stirred for about 24 hours. After that, the mixture was washed with distilled water ( $3 \times 20 \mathrm{~mL})$ and extracted with chloroform ( $3 \times 20 \mathrm{~mL})$. The organic phase was dried by anhydrous $\mathrm{K}_{2} \mathrm{CO}_{3}$. The solvent was removed by rotary evaporation. The crude product was purified by silica gel column chromatography (the eluent as following $-4 n$ heptane: 1 ethyl acetate) to give the isolated product as a white crystalline solid $\left(1.172 \mathrm{~g}, \mathrm{R}_{\mathrm{f}}=\right.$ 0.57 , yield: $74.34 \%$ ).

${ }^{1} \mathrm{HNMR}\left(500 \mathrm{MHz}, \mathrm{CDCl}_{3}\right), \delta(\mathrm{ppm}) 7.72(\mathrm{~m}$, 2H), 7.69 (m, 2H), 7.57 (t, 2H), 6.87 (br s, 2H).

\section{RESULTS AND DISCUSSION}

The synthesis of monomers BDP and DiBDP are shown in Scheme 1. Monomer BDP was synthesized by using copper-catalyzed amidation 3,3'-dibromo-2,2'-bithiophene at the reflux temperature, in presence of $\mathrm{CuI}$ as the catalyst, DMEDA as the ligand for coupling amides with thiophene rings, toluene as solvent and $\mathrm{K}_{2} \mathrm{CO}_{3}$ as the base. The reaction proceeded with the formation of a dark-blue complex of copper (I) iodide and DMEDA and a subsequent brown mixture after 24 hours. After completion of reaction, the monomer was attained by extracting with chloroform, washing with distilled water and purification via column chromatography using the eluent of $n$-heptane and ethyl acetate ( $/ / v: 4 / 1)$. It is necessary to brominate of BDP monomer as intermediated product for forthcoming reactions such as conjugated oligomerization and conjugated polymerization. So that the achieved BDP monomer reacted with 2 equivalent of NBS based on the nucleophilic substitution mechanism to form DiBDP monomer. The reation was carried out in chloroform as a solvent at $0{ }^{\circ} \mathrm{C}$ in 24 hours. Then, the reaction mixture was extracted with chloroform, washed with distilled water several times and purified by column chromatography to give a pale yellow solid in high yield (74.34\%). 


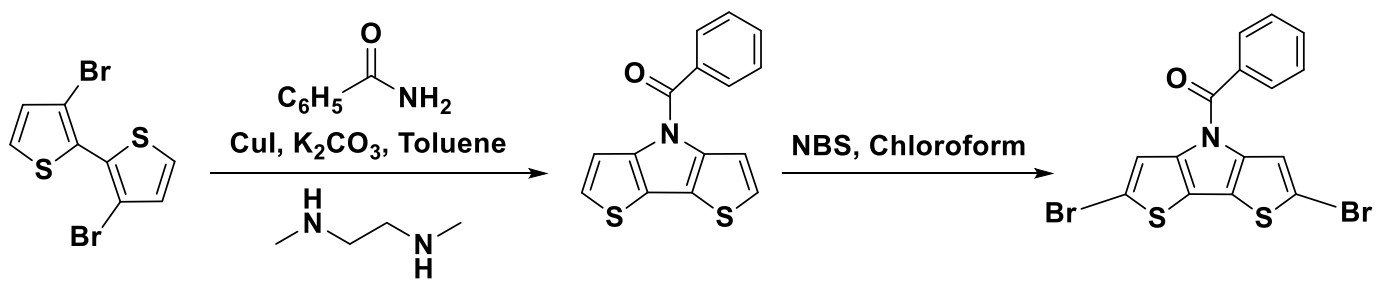

Scheme 1. Synthesis routes of BDP and DiBDP monomers.

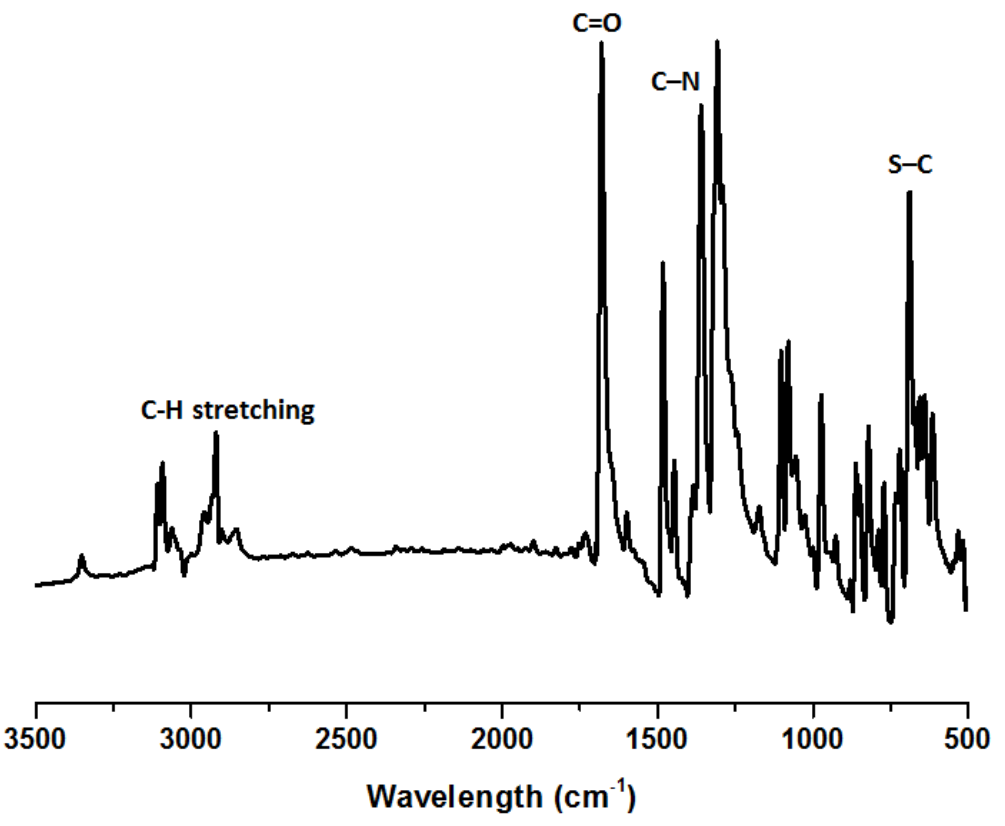

Figure 3.1. FT-IR spectrum of monomer BDP

The ATR FT-IR spectra of monomer BDP (Fig 3.1) displayed several peaks between 2921 and $3109 \mathrm{~cm}^{-1}$ which contributed to $\mathrm{C}-\mathrm{H}$ stretching vibrations of the benzyl groups. The peak at $1680 \mathrm{~cm}^{-1}$, which was ascribed to the $\mathrm{C}=\mathrm{O}$ stretching vibrations clearly proved for the existence of the $N$-acyl group in this monomer structure. The peaks at $1482 / 1443 \mathrm{~cm}^{-1}$ and the bands in range of 656 to $974 \mathrm{~cm}^{-1}$ are assigned to the aromatic $\mathrm{C}-\mathrm{C}$ stretching vibrations and aromatic $\mathrm{C}-\mathrm{H}$ deformation vibrations respectively. Whereas the bands from 1307 to $1384 \mathrm{~cm}^{-1}$ are assigned to the aromatic C-N stretching vibrations of the pyrrole units. In addition, the bands in range of $690-721 \mathrm{~cm}^{-1}$ and $615 \mathrm{~cm}^{-1}$ are ascribed in order to the thiophene C$\mathrm{S}-\mathrm{C}$ bending and $\mathrm{S}-\mathrm{C}$ stretching vibrations.

In the ${ }^{1}$ HNMR spectrum of monomer BDP (Fig. 3.2), the doublet peak at $7.73 \mathrm{ppm}$, the triplet peak at $7.65 \mathrm{ppm}$ and the triplet peak at $7.55 \mathrm{ppm}$ respectively corresponded to the five protons on the benzene ring, in particular, two at positions ' $\mathrm{d}$ ', one at position ' $\mathrm{f}$ ' and two at positions 'e'. The doublet peak at $7.1 \mathrm{ppm}$ corresponded to the two protons on the thiophene rings 'peak b'. The broad singlet peak at 6.85 ppm was assigned to two protons left on the thiophene rings 'peak a'. The chemical shifts 
along with the integrals of obtained signals were suitable with the structural formula of this monomer. These results indicated that copper- catalyzed amidation reaction successfully forming the desired monomer.

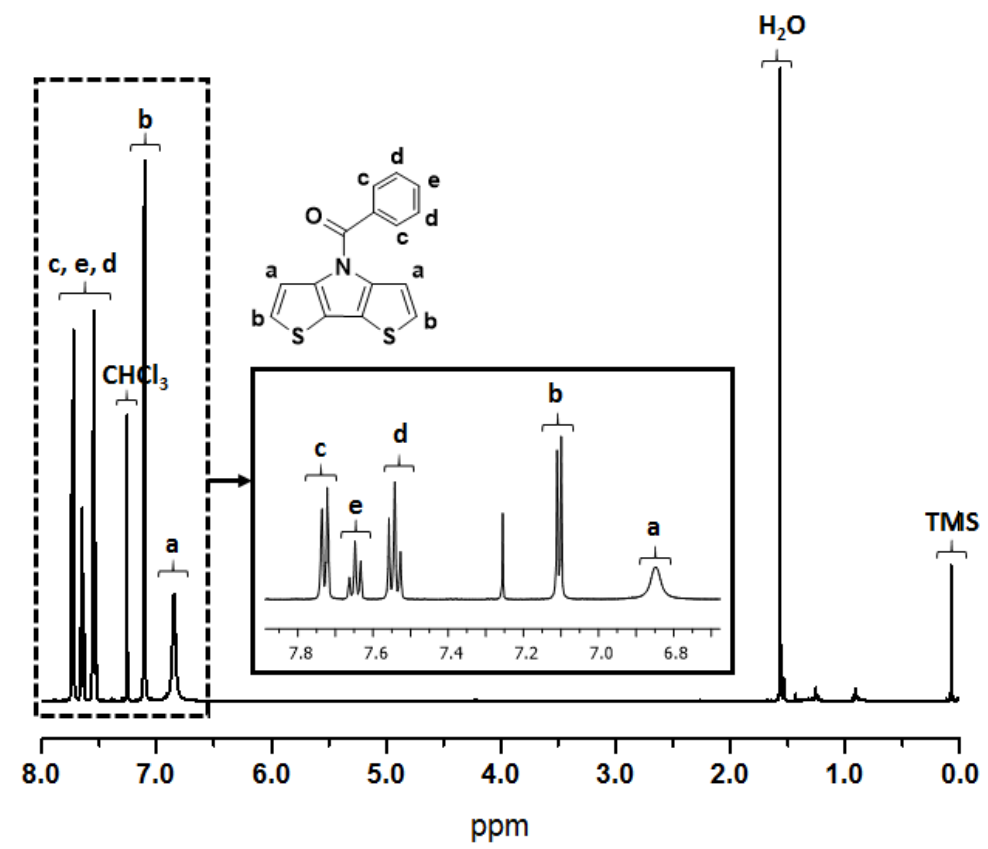

Figure 3.2. ${ }^{1} \mathrm{H}$ NMR spectrum of monomer $\mathrm{BDP}$ in $\mathrm{CDCl}_{3}$

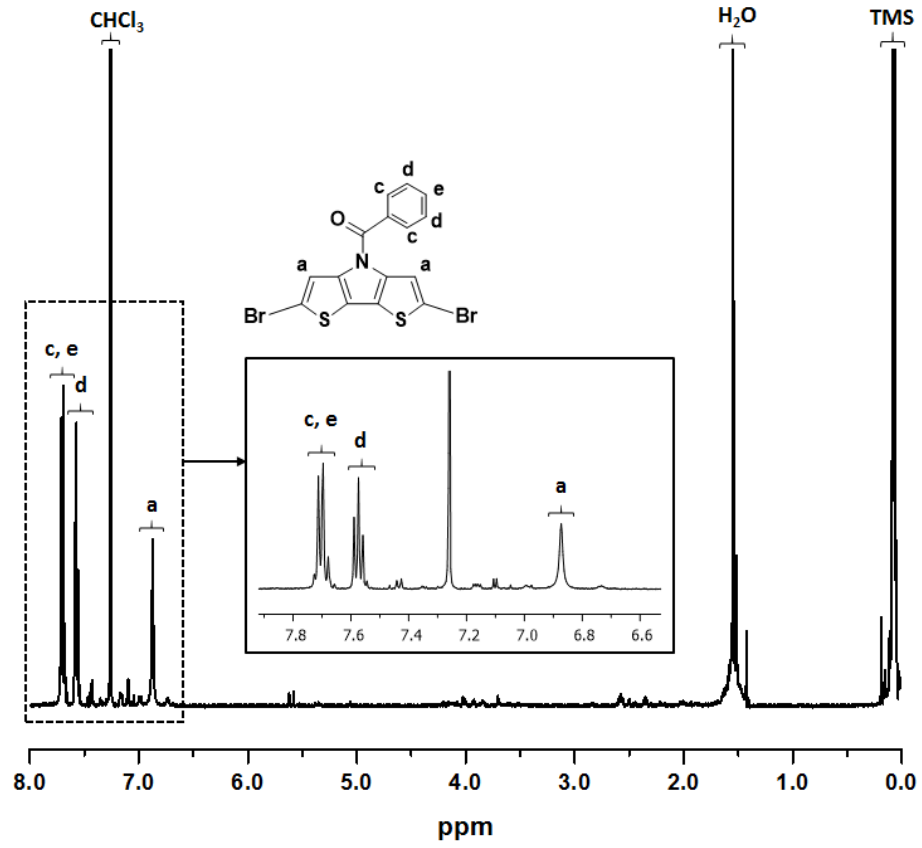

Figure 3.3. ${ }^{1} \mathrm{H}$ NMR spectrum of monomer DiBDP in $\mathrm{CDCl}_{3}$ 
Figure 3.3 shows the ${ }^{1} \mathrm{HNMR}$ spectrum of DiBDP monomer. The signal at $7.72 \mathrm{ppm}$ was assigned to the two protons at position ' $d$ ' on the benzene ring. The multiple peak at $7.69 \mathrm{ppm}$ of the proton at position (f) was overlapped with the peak coming from protons at position ' $d$ '. The broad singlet peak at $6.87 \mathrm{ppm}$ corresponded to the two protons at position ' $\mathrm{a}$ ' on the thiophene rings. Besides that, in the ${ }^{1} \mathrm{HNMR}$ spectrum of monomer DiBDP, there is no signal observed at $7.1 \mathrm{ppm}$. This demonstrated that the two protons at the position ' $b$ ' of monomer BDP were replaced by two bromine atoms. These results indicated that brominate replacement reaction successfully forming the desired monomer.

However, in the brominating process, side by side the desired monomer - DiBDP, there was still have one side product (MoBDP) which only one proton at position ' $b$ ' of BDP monomer was replaced by bromine atom (Fig.3.4). Here the separation of two components (DiBDP and MoBDP) depends upon the extent absorption to stationary phase. The rate of the movement $\left(R_{f}\right)$ of DiBDP is 0.57 while the MoBDP's $\mathrm{R}_{\mathrm{f}}$ is only 0.45. DiBDP with lower absorption affinity to the silica moved faster and eluted out first (yield: $74.34 \%$ ) and vice versa MoBPD with greater absorption to stationary phase was eluted out later with a yield around $15 \%$. This side product (MoBDP) was also characterized by ${ }^{1} \mathrm{HNMR}$ spectroscopy to clarify its structure. Based on the chemical shifts at $7.1 \mathrm{ppm}$ and the integrals of these signal in the ${ }^{1} \mathrm{HNMR}$ spectra of BDP, DiBDP and MoBDP, the relative ratio of the amount of equivalent protons at the position ' $b$ ' was displayed clearly (Fig. 3.5).

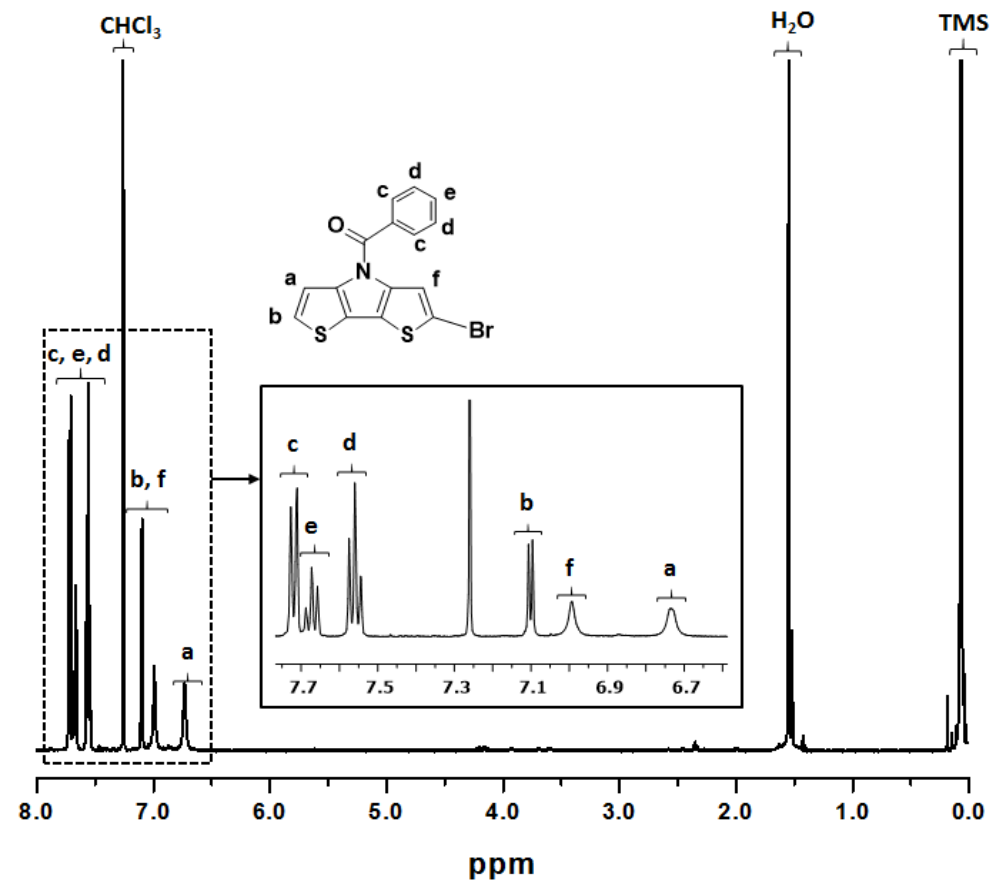

Figure 3.4. ${ }^{1} \mathrm{H}$ NMR spectrum of monomer $\mathrm{MoBDP}$ in $\mathrm{CDCl}_{3}$ 


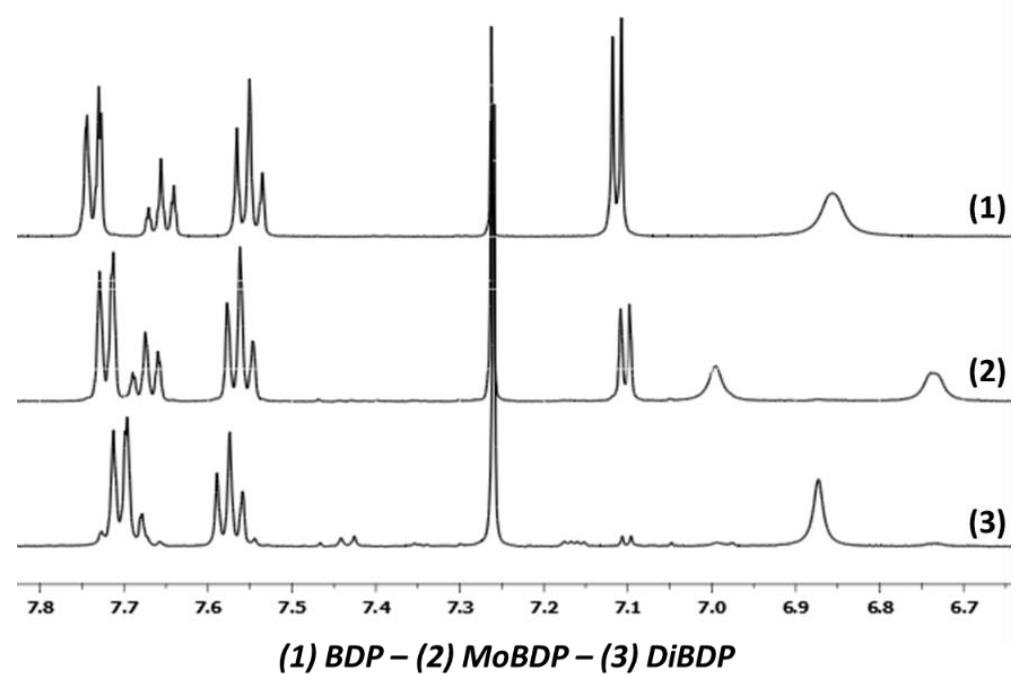

Figure 3.5. Comparison ${ }^{1} \mathrm{HNMR}$ spectra of the monomers BDP, DiBDP, $\mathrm{MoBDP}$ in $\mathrm{CDCl}_{3}$

\section{CONCLUSION}

In conclusion, the derivate of a new class of dithieno[2,3-b:2',3'-d]pyrrole incorporating with $\mathrm{N}$-acyl group, particularly $\mathrm{N}$-benzoyl dithieno[2,3-b:2',3'-d]pyrrole monomer, has been achieved via copper-catalyzed amidation reaction. Then monomer BDP was imposed bromine by the brominating replacement reaction to create 2,6-dibromo- $n$-benzoyl dithieno[2,3b:2',3'-d]pyrrole monomer. The chemical structures of these monomers were clarified by
${ }^{1}$ HNMR and FT-IR analyses. Further studies on these monomers are underway in our laboratory for generation of $\mathrm{D}$-A conjugated polymers.

ACKNOWLEDGEMENT: This research was supported by project "TSĐH-2015-CNVL-50" from Ho Chi Minh City University of Technology - Vietnam National University - Ho Chi Minh City, 268 Ly Thuong Kiet, District 10, Ho Chi Minh City 70000, Viet Nam. 


\section{Các monomer họ Dithienopyrrole với vai trò làm đơn vị cấu trúc cho điện tử, ứng dụng trong tổng hợp các polymer dẫn điện có cấu trúc dạng cho - nhận điện tử}

- Nguyễn Hũ̃u Tâm ${ }^{2}$

- Nguyễn Anh Thư ${ }^{1}$

- Nguyễn Quốc Việt ${ }^{1}$

- Nguyễn Thành Trung ${ }^{2}$

- Nguyễn Trần Hà ${ }^{2}$

${ }^{1}$ PTN Trọng điểm Quốc gia Vật liệu Polyme \& Compozit - ĐHQG-HCM.

${ }^{2}$ Khoa Công nghệ Vật liệu, Trường Đại học Bách Khoa - ĐHQG-HCM.

\section{TÓM TẮT}

Một monomer mói của ho N-acyl dithieno[2,3-b:2',3'-d]pyrrole (DTP), N-benzoyl dithieno[2,3-b:2',3'-d]pyrrole (BDP), đã được tổng hợp thành công bằng phản ứng amide hoá sủ dụng hệxúc tác đồng. Monomer này được thục hiện phản úng brom hoá để tạo ra monomer 6dibromo-n-benzoyl dithieno[2,3-b:2',3'd]pyrrole (DiBDP). Quy trình tổng hợp và khảo

Tù khóa: Polymer dẫn có cấu trúc dạng cho - nhận điện tử (D-A), pin mặt trời hũu co; phản úng trùng ngung Suzuki.

\section{REFERENCES}

[1] G. Chamberlain, Organic solar cells: A review, Sol.Cells, 1983, vol. 8, pp. 47-83.

[2] J. Nelson, Organic photovoltaic films, Current Opinion in Solid State Mater. Sci., 2002, vol. 6, pp. 87-95. sát tính chất của các monomer này, bao gồm kết quả phân tích đánh giá bằng ${ }^{1} H N M R$ và FT-IR, sẽ đuợc trình bày trong nghiên cứu này. Monomer BDP và DiBDP sẽ được sủ dụng làm nguyên liệu chính cho phản úng trùng ngung Suzuki tổng hơp các polymer dẫn có cấu trúc dạng cho - nhận điện tư. 
[5] Y.-C. Chen, C.-Y. Yu, Y.-L. Fan, L.-I. Hung, C.-P. Chen and C. Ting, Low-bandgap conjugated polymer for high efficient photovoltaic applications, Chem. Commun., 2010, 46, 6503-6505.

[6] M. Zhang, X. Guo and Y. Li, Advanced Energy Materials, 2011, 1, 557-560.

[7] Y. Zou, A. Najari, P. Berrouard, S. Beaupré, B. Réda Aich, Y. Tao and M. Leclerc, $A$ thieno [3, 4-c] pyrrole-4, 6-dione-based copolymer for efficient solar cells, J. Am. Chem. Soc., 132, 5330-5331, 2010.

[8] T.-Y. Chu, J. Lu, S. Beaupr e, Y. Zhang, J.-R. m. Pouliot, S. Wakim, J. Zhou, M. Leclerc, Z. $\mathrm{Li}$, J. Ding and Y. Tao, Bulk heterojunction solar cells using thieno[3,4-c]pyrrole-4,6dione and dithieno[3,2-b:2',3'-d]silole copolymer with a power conversion efficiency of 7.3\%. J. Am. Chem. Soc., 2011, 133, 4250 4253.

[9] H. Zhou, L. Yang, A. C. Stuart, S. C. Price, S. Liu and W. You, Angew. Development of Fluorinated Benzothiadiazole as a Structural Unit for a Polymer Solar Cell of 7\% Efficiency, Chem., Int. Ed., 2011, 50, 29952998.

[10] C. M. Amb, S. Chen, K. R. Graham, J. Subbiah, C. E. Small, F. So and J. R. Reynolds, Dithienogermole as a fused electron donor in bulk heterojunction solar cells, J. Am. Chem. Soc., 2011, 133, $10062-$ 10065
[11] J.-M. Jiang, P.-A. Yang, H.-C. Chen and K.H. Wei, Synthesis, Characterization, and Photovoltaic Properties of a Low-Bandgap Copolymer Based on 2,1,3-Benzooxadiazol, Chem. Commun., 2011, 47, 8877-8879.

[12] H. Zhou, L. Yang, S. Stoneking and W. You, A Weak Donor-Strong Acceptor Strategy to Design Ideal Polymers for Organic Solar Cells, ACS Appl. Mater.Interfaces, 2010, 2, 1377-1383.

[13] H. Zhou, L. Yang, S. C. Price, K. J. Knight and W. You, Enhanced Photovoltaic Performance of Low-Bandgap Polymers with Deep LUMO Levels, Angew. Chem., Int. Ed., 2010, 49, 7992-7995.

[14] Rasmussen SC, Ogawa K, Rothstein SD, Synthetic approaches to band gap control in conjugated polymeric materials. In: Nalwa HS, editor. Handbook of Organic Electronics and Photonics, vol. 1. Stevenson Ranch, CA: American Scientific Publishers; 2008. p. 1-50.

[15] Baumgartner T, Conjugated heterocyclic fused biothiophene materials, J Inorg Organomet Polym Mater, 2005, 15, 389409.

[16] Evenson SJ, Rasmussen SC, NAcyldithieno[3,2-b:2,3-d]pyrroles: second generation dithieno[3,2-b:2,3-d]pyrrole building blocks with stabilized energy levels. Org Lett, 2010, 12, 4054-7. 